\title{
Erratum to: Autoantibodies to desmogleins 1 and 3 in patients with lichen planus
}

\author{
Vahide Lajevardi $^{1} \cdot$ Zahra Halaji $^{1} \cdot$ Forugh Ghaedi $^{1} \cdot$ Nazi Saljoughi $^{2}$
}

Published online: 8 August 2017

(C) Springer-Verlag GmbH Germany 2017

\section{Erratum to: Arch Dermatol Res \\ DOI 10.1007/s00403-017-1756-x}

The given and the family names of all the co-authors were swapped in the original publication. The correct author names should read as follows:

Vahide Lajevardi, Zahra Halaji, Forugh Ghaedi, Nazi Saljoughi.

The online version of the original article can be found under doi:10.1007/s00403-017-1756-x.

Forugh Ghaedi

f_ghaedi@edc.mui.ac.ir

1 Department of Dermatology, Razi Hospital, Tehran

University of Medical Sciences, Tehran, Iran

2 Azad University of Medical Sciences, Tehran, Iran 